\title{
Viral load of various tissues of rainbow trout challenged with viral haemorrhagic septicaemia virus at various stages of disease
}

\author{
B. Oidtmann*, C. Joiner, D. Stone, M. Dodge, R. A. Reese, P. Dixon \\ Cefas Weymouth Laboratory, Weymouth, Dorset DT4 8UB, UK
}

\begin{abstract}
Market-sized rainbow trout Oncorhynchus mykiss were challenged by waterborne exposure to viral haemorrhagic septicaemia virus (VHSV isolate of genogroup Ia). Fish were sampled at 4 stages of infection (before onset of clinical signs, clinically affected fish, mortalities and survivors) and the viral load determined in (1) internal organs, (2) muscle tissue and (3) brain and gill tissue. Virus levels were determined by virus titration and real-time RT-PCR. VHSV was detected by either method in the majority of fish before onset of clinical signs and in the survivor group as well as in all fish in the clinically affected fish and mortality groups. Mean virus amounts per mg of tissue determined by virus titration $\left(\mathrm{TCID}_{50}\right.$ ) or real-time RT-PCR (copy number) were $>10^{4}$ in preclinical fish, $>10^{3.8}$ in clinically affected fish, $>10^{3.9}$ in mortalities and $>10^{1.2}$ in survivors. Virus levels tended to be highest in the internal organs of subclinical and clinically affected fish and in brain and gill tissue of survivors. The results demonstrate that significant levels of VHSV can be found in tissues of rainbow trout that may be marketed for human consumption, which may have relevance for the biosecurity of VHS-free areas.
\end{abstract}

KEY WORDS: Viral haemorrhagic septicaemia virus · VHSV · Rainbow trout · Oncorhynchus mykiss · Viral load

Resale or republication not permitted without written consent of the publisher

\section{INTRODUCTION}

Viral haemorrhagic septicaemia (VHS) is a rhabdovirus disease that causes significant losses in farmed rainbow trout Oncorhynchus mykiss around Europe (Olesen 1998) and more recently has led to disease in a wide range of wild freshwater finfish species in the Great Lakes basin of North America (Elsayed et al. 2006, Groocock et al. 2007, Lumsden et al. 2007). VHS virus (VHSV) has also been isolated from several marine species, in which it is only occasionally associated with disease (Skall et al. 2004, 2005).

Four genogroups (I to IV) of VHSV have been described, and genogroups I and IV are further divided into subgroups. Genogroup Ia is the subgroup most frequently associated with outbreaks of the disease in cultured rainbow trout, but strains from other genogroups have occasionally been isolated from outbreaks in rainbow trout farms (Einer-Jensen et al. 2004, Snow et al. 2004, Raja-Halli et al. 2006). Recently, genogroup $\mathrm{IVb}$ has been identified in a range of freshwater fish species in the Great Lakes region of North America (Elsayed et al. 2006, Groocock et al. 2007, Lumsden et al. 2007). Finding that another genogroup has affected freshwater species is very important because this could present a substantial threat for aquaculture of freshwater fish species.

In 2006, a VHS outbreak occurred for the first time in a farmed rainbow trout population in England, UK (Stone et al. 2008). In a phylogenetic analysis, the isolated virus clustered with isolates of genogroup Ia, suggesting that the virus was most probably derived from a freshwater salmonid species. An epidemiological investigation into the source of the outbreak was undertaken, but no pathway of introduction was conclusively demonstrated. 
Conditions can be imposed on movements of live fish into areas free from diseases listed in European legislation on animal health requirements for aquaculture animals and their products (Council Directive 91/67/ EEC and 2006/88), or named by the World Organisation for Animal Health (OIE 2008). However, conditions may not be applied if the fish are imported for human consumption and have been slaughtered and eviscerated before dispatch (Council Directive 91/67/ EEC and 2006/88; OIE 2008).

One route considered during the investigation of the 2006 VHS outbreak in England was the release of infected material from a smokery/processing site upstream from the affected site. This potential route prompted further investigations to assess the risks associated with import of products from VHSV infected fish. A paucity of data on viral load in tissues imported for human consumption was found. The purpose of our study was to investigate (1) virus levels that might be found in rainbow trout tissues imported for human consumption (e.g. muscle and head tissue) and (2) virus levels in fish tissues at various stages of infection.

To check reliability, some samples were analysed both by real-time RT-PCR and virus titration; however, for reasons of costs and practical (logistic) limitations in parallel processing of multiple samples by virus titration, the remainder were analysed by real-time RTPCR only.

The results can be used to inform assessments of the risk of introduction of VHSV through the import of rainbow trout products for human consumption into disease-free zones or countries.

\section{MATERIALS AND METHODS}

Virus and titration. The VHSV isolate J167 1.1 (genogroup Ia), first found in rainbow trout in the UK by Stone et al. (2008), was thawed from storage at $-80^{\circ} \mathrm{C}$ and then grown and titrated in bluegill Lepomis macrochirus fibroblast cells (BF-2, ATCC CCL 91) (Wolf et al. 1966) in 96-well microtitre plates (Falcon). The $50 \%$ tissue culture infectious dose (TCID $_{50}$; Kärber 1931) was determined by end-point dilution assays. Serial $\log _{10}$ dilutions (inoculation volume: $180 \mu \mathrm{l}$; dilutions from $10^{-1}$ to $10^{-8}$; 6 replicates for each dilution) were inoculated onto the cells, which were then incubated at $15^{\circ} \mathrm{C}$ for $7 \mathrm{~d}$ and scored for cytopathic effect (CPE; Parry \& Dixon 1997).

Fish. Market-sized rainbow trout (average weight, $283 \mathrm{~g}$ ) were obtained from a rainbow trout farm in England that had been inspected twice a year for several years by the competent authority before the fish were purchased and no occurrence of VHSV was found before or after the fish were obtained. During the 2 wk acclimation period at $10^{\circ} \mathrm{C}, 10$ randomly selected trout were tested for the virus on BF-2 cells and Chinook salmon Oncorhynchus tshawytscha embryo cells (CHSE-214, ATCC CRL 1681) (Lannan et al. 1984) with samples of the brain, head kidney, spleen, liver and gills.

Challenge experiments. Expt 1: Determination of virus concentration to be used in the main challenge of market-size rainbow trout: Three groups of 30 market-sized rainbow trout in 3001 tanks were exposed to virus concentrations of $10^{2}, 10^{3}$ and $10^{4} \mathrm{TCID}_{50} \mathrm{ml}^{-1}$ in an immersion challenge at $10 \pm 0.5^{\circ} \mathrm{C}$. The water flow through the tanks was suspended for the $4 \mathrm{~h}$ of exposure. The fish were monitored twice daily for the next 6 wk. Mortalities were removed at each check and samples of internal organs taken. A negative control group ( $\mathrm{n}=30$ ), mock challenged with cell culture maintenance medium, was kept under similar conditions. Presence or absence of VHSV in samples of internal organs (consisting of equal parts of kidney, spleen and liver) from mortalities and control fish was measured by RT-PCR.

Expt 2: Challenge trials to generate fish at various stages of infection (main challenge): One hundred fish divided into 3 groups of 33 or 34 each were placed into three 3001 tanks and exposed to a high challenge dose of $5.7 \times 10^{5} \mathrm{TCID}_{50} \mathrm{ml}^{-1} \mathrm{VHSV}$ for $4 \mathrm{~h}$. Another 2 groups of 100 fish each were placed into two 9001 tanks and exposed to a low dose of $5 \times 10^{4} \mathrm{TCID}_{50} \mathrm{ml}^{-1}$ VHSV for $4 \mathrm{~h}$. A control group of 30 fish was mock challenged with cell maintenance medium in a $300 \mathrm{l}$ tank. Water temperature was held at $10 \pm 0.5^{\circ} \mathrm{C}$ throughout the challenge. The fish were monitored twice daily for the next $6 \mathrm{wk}$ and some were removed from tanks throughout the $6 \mathrm{wk}$ at different stages of disease and classified as follows:

(1) After the first onset of mortalities in each tank, clinically healthy fish were sampled from the same tank and classed as 'preclinical', meaning they were potentially infected and in the incubation phase of infection.

(2) When showing clear signs of disease fish were classed as 'clinical'.

(3) Mortalities collected within $12 \mathrm{~h}$ of their death were classed as 'mortalities'.

(4) After mortalities had ceased remaining fish were classed as 'survivors'.

Tissue groups were sampled as follows:

(1) equal weights of liver, spleen and head kidney tissue for a total of $1 \mathrm{~g}$;

(2) approximately $0.3 \mathrm{~g}$ of brain tissue and approximately $0.7 \mathrm{~g}$ gill lamellae without cartilage for a total of $1 \mathrm{~g}$;

(3) muscle tissue sampled below the dorsal fin and above the lateral line for a total of $1 \mathrm{~g}$. 
Dissection instruments were wiped clean between sampling of the various tissues from a single fish and a new set of sterilised instruments were used for each fish. The amount of virus in the samples was determined by both real-time RT-PCR and virus titration for 5 fish from each clinical stage and only by real-time RT-PCR for a further 25 fish per clinical stage.

Tissue homogenisation. For Expt 1, $1 \mathrm{~g}$ of tissue from each tissue group was suspended in $9 \mathrm{ml}$ of transport medium (Glasgow modification of minimal essential medium [GMEM] supplemented with 10\% newborn calf serum, $2 \mathrm{mM}$ L-glutamine and $1 \%$ antibiotic + antimycotic solution; all from Sigma) for $24 \mathrm{~h}$ at $4{ }^{\circ} \mathrm{C}$. The tissue was then homogenised with pestle, mortar and sterile sand and centrifuged at $2700 \times g$ for $15 \mathrm{~min}$ at $4^{\circ} \mathrm{C}$. For Expt 2, tissues from the 20 fish $(5$ fish $\times$ 4 clinical stages) that were analysed by both real-time RT-PCR and virus titration were homogenised as described for Expt 1. From the remaining 100 fish (25 per clinical stage), $0.2 \mathrm{~g}$ of each tissue type was taken from each fish and stored in RNA-later ${ }^{\mathrm{TM}}$ at $4^{\circ} \mathrm{C}$. Tissues were later homogenised in a homogenizer (Fast Prep FP120/ Bio 101) in tubes containing $800 \mu \mathrm{l}$ of transport medium at speed 4 for two $20 \mathrm{~s}$ bursts.

RNA extraction. For Expt $1100 \mu \mathrm{l}$ was extracted in $1 \mathrm{ml}$ of Trizol reagent (Invitrogen) from each homogenate following the manufacturer's guidelines and suspended in $50 \mu \mathrm{l}$ of molecular grade water. For Expt 2 RNA extraction was performed as in Expt 1 for fish analysed by both methods. For fish analysed by real-time RT-PCR only, $50 \mu$ l of homogenate was added to $1 \mathrm{ml}$ of Trizol reagent and the purified RNA was suspended in $50 \mu \mathrm{l}$ of molecular grade water.

Reverse transcription. For Expt 1, reverse transcription (RT) was performed at $37^{\circ} \mathrm{C}$ for $1 \mathrm{~h}$ in a $20 \mu \mathrm{l}$ volume solution comprising $1 \times$ Moloney murine leukemia virus reverse transcriptase (M-MLV-RT) reaction buffer (50 mM Tris [pH 8.3], $75 \mathrm{mM} \mathrm{KCl,} 10 \mathrm{mM}$ DTT, $3 \mathrm{mM}$ $\mathrm{MgCl}_{2}$ ) containing $5.0 \mathrm{mM}$ dNTP mix, $100 \mathrm{pmol}$ of VHSV degenerate primer R1 (5'-CTT CTT TGG AGG GCA AAC NAT H-3') (Stone et al. 1997, Dixon et al. 2003), 200 units M-MLV-RT (Promega), 40 units of Rnasin ${ }^{\circledR}$ and $5 \mu \mathrm{l}$ of the total RNA extracted above.

For Expt 2, RT was performed as for Expt 1 except $0.5 \mu \mathrm{g}$ random hexadeoxynucleotides were substituted for the VHSV degenerate primer R1, and only $4 \mu \mathrm{l}$ of the total RNA extracted was used. Solutions of cDNA were prepared as standards for the real-time PCR by combining $4 \mu \mathrm{l}$ of RNA extract from control fish with $1 \mu \mathrm{l}$ from the RNA dilution series established from viral RNA. For the RT reaction, 500 ng random hexadeoxynucleotides and $20 \mathrm{U}$ of Rnasin ${ }^{\circledR}$ were used.

Traditional PCR. A traditional PCR assay was used in Expt 1 in which a 468 bp segment corresponding to nucleotides 340 to 807 of the glycoprotein (G) gene was amplified with degenerate VHSV primers F3 (5'-GAT CAG GTC CCC CAR RTC NGT-3') and R1. This was followed by a semi-nested PCR assay with primers F1 (5'-CAG TCC CCA GGG ATG ATG NCC3') and R1 (Stone et al. 1997, Dixon et al. 2003). Both $\mathrm{PCR}$ reactions were performed in a $50 \mu \mathrm{l}$ reaction volume containing $1 \times \mathrm{GoTaq}^{\circledR}$ flexi buffer, $2.5 \mathrm{mM} \mathrm{MgCl}_{2}$ solution, $5.0 \mathrm{mM}$ dNTPs mix, $100 \mathrm{pmol}$ of each primer, 2.5 units of GoTaq polymerase (Promega), $2.5 \mu \mathrm{l} \mathrm{RT}$ product and $2.5 \mu \mathrm{l}$ of the PCR reaction from the firstround PCR. The reaction mix was overlaid with mineral oil and subjected to 35 temperature cycles of $1 \mathrm{~min}$ at $95^{\circ} \mathrm{C}, 1 \mathrm{~min}$ at $55^{\circ} \mathrm{C}$ and $1 \mathrm{~min}$ at $72^{\circ} \mathrm{C}$, followed by a final extension step of $10 \mathrm{~min}$ at $72^{\circ} \mathrm{C}$ in a thermocycler (model DNA Engine 2 Tetrad, MJ Research). Amplified products were electrophoresed in a $2 \%$ (w/v) agarose/TAE (40 mM Tris-acetate, pH 7.2, $1 \mathrm{mM}$ EDTA) gel containing $1.0 \mu \mathrm{g} \mathrm{ml}^{-1}$ ethidium bromide at $120 \mathrm{~V}$ for $30 \mathrm{~min}$ and viewed under UV light.

Quantification of virus. $50 \%$ tissue culture infec-

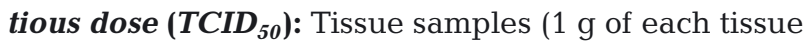
group) were homogenised in $9 \mathrm{ml}$ of transport medium and the homogenate centrifuged at $2700 \times g$ for $15 \mathrm{~min}$ at $4{ }^{\circ} \mathrm{C}$. A $20 \mu \mathrm{l}$ volume of the supernatant was mixed with $180 \mu \mathrm{l}$ of GMEM (supplemented with $10 \%$ fetal calf serum, $2 \mathrm{mM}$ L-glutamine and $1 \%$ antibiotic + antimycotic solution; all from Sigma) and titrations were done as described in 'Virus and tritration'. Taking all dilution steps into account, the amount of tissue represented by the first $180 \mu \mathrm{l}$ inoculation volume was determined to be $1.8 \mathrm{mg}$.

Virus and RNA purification for real-time $R T-P C R$ standard curve: Tissue culture flasks $\left(15 \times 75 \mathrm{~cm}^{2}\right)$ containing a monolayer of BF-2 cells were inoculated with VHSV J167. When full cytopathic effect (CPE) was reached, virus was harvested and purified as previously described (Hill et al. 1975) except that TNE buffer (10 mM Tris, 0.1 M NaCl, 1 mM EDTA, pH 7.2) was used. The band containing the virus was removed from the gradient, diluted in TNE and centrifuged at $35000 \times g$ for $1 \mathrm{~h}$, and the virus pellet was resuspended in $200 \mu \mathrm{l}$ TNE. Viral RNA was extracted from $100 \mu \mathrm{l}$ of the purified virus preparation using the RNA tissue mini kit (Qiagen) and dissolved in $50 \mu$ l of RNase/ DNase free water. The RNA concentration was determined with $2 \mu$ l of the RNA suspension in a spectrophotometer (model ND-1000, NanoDrop). A prepared RNA stock solution contained a calculated concentration of $1 \times 10^{8}$ copies VHSV $\mu l^{-1}$. RNA was extracted from $50 \mu \mathrm{l}$ samples of 1:10 w/v tissue homogenates of control fish, dissolved in $30 \mu \mathrm{l}$ of RNase/ DNase free water and then pooled. A volume of $30 \mu \mathrm{l}$ of the control fish RNA was spiked with $10 \mu \mathrm{l}$ of serially diluted viral RNA $\left(2 \times 10^{6}\right.$ to $\left.6.25 \times 10^{4}\right)$ and $4 \mu$ lof the combined RNA was then used in a $20 \mu$ l RT-PCR reaction to give 
final virus copies of $2 \times 10^{5}, 1 \times 10^{5}, 5 \times 10^{4}, 2.5 \times 10^{4}$, $1.25 \times 10^{4}$ and $6.25 \times 10^{3}$ per reaction.

Real-time RT-PCR assay (Expt 2): Before the realtime $\mathrm{PCR}$, the reverse transcription reactions were heated to $70^{\circ} \mathrm{C}$ for $10 \mathrm{~min}$. The $20 \mu \mathrm{l} \mathrm{PCR}$ reaction consisted of $2 \mu \mathrm{l}$ reverse transcription reaction mix, along with $10 \mu$ l of TaqMan ${ }^{\circledR}$ universal PCR master mix (No AmpErase ${ }^{\circledR}$ UNG, Applied Biosystems part number 4324018) and $300 \mathrm{nM}$ forward primer VHSV-N-FOR (5'-GAC TCA ACG GGA CAG GAA TGA-3'), 300 nM reverse primer VHSV-N-REV (5'-GGG CAA TGC CCA AGT TGT T-3') and $100 \mathrm{nM}$ probe VHSVN-PROBE (5'-TGG GTT GTT CAC CCA GGC CGC-3') (Chico et al. 2006). Molecular-grade water was added to make up the total reaction volume of $20 \mu$ l. Reactions were run in an Applied Biosystems Step One ${ }^{\text {TM }}$ Realtime PCR system. The same volume $(2 \mu \mathrm{l})$ of cDNA standards and sample cDNA was subjected to the realtime PCR reaction. Each sample cDNA and cDNA standard solution was run in triplicate. Each tray also contained PCR negative controls, RNA extraction negative controls and positive controls of the RT. For absolute quantitation, VHSV copy numbers in the samples were calculated from the sample threshold cycle number $\left(C_{t}\right)$ and the standard curve regression equation.

Establishing standard curve, assessment of linearity of the standard curve and calculation of its slope: Solutions of cDNA generated from spiked tissue containing a calculated RNA copy number of $6.25 \times 10^{3}$ to $2 \times 10^{5}$ were run alongside each set of samples on the 48 well plate. Regression analysis was undertaken for the $C_{t}$ values and the total virus copy number entered into the cDNA reaction. The efficiency $(E)$ of the PCR reactions was calculated by using the formula $E=$ $2^{-1 / S}-1$, with $S$ being the slope of the standard curve.

Calculation of copy numbers present from triplicate samples: The real-time thermocycler reported the copy number submitted to a PCR reaction based on the mean from up to 3 replicate samples for which a $C_{t}$ value had been determined. If 1 or 2 samples did not reach the threshold (due to insufficient amount of template cDNA in the sample), the copy number reported is based only on those preparations that did yield a $C_{t}$ value. This potentially overestimates the copy number in the sample. In such cases, the mean value from triplicate preparations was recalculated with the estimated copy numbers in the preparations that gave results within the given $C_{t}$ threshold and a value of 0 for the remaining preparations. Copy numbers reported for each sample were adjusted to $1 \mathrm{mg}$ of tissue. Copy numbers in each reaction were calculated based on the standards run on the respective 96 well plate.

Statistical analyses. Virus quantities determined by real-time RT-PCR from the 5 fish sample analysed by both real-time RT-PCR and virus titration were compared with virus quantities in the 25 fish analysed by real-time RT-PCR only at each clinical stage using a 2 -sample $t$-test of the means of the $\log _{10}$ values (excluding negative tests). Virus quantities in samples analysed by both real-time RT-PCR and virus titration were compared using paired $t$-tests. The mean virus quantities determined by titration or real-time RT-PCR (log-transformed data) were compared by ANOVA between the various clinical stages and tissue types.

A regression model was used to compare performance of the 2 methods (TCID 50 and real-time RT-PCR). Sixty samples (5 fish from each clinical stage, 4 clinical stages, 3 types of tissue) were analysed by both methods, but samples for which one or both methods gave a negative result (no virus detected) were excluded from the analysis, leaving 44 paired samples in this analysis. The correlation coefficient was calculated for all 60 samples, and again only for those results where virus was detected by both methods $(n=44)$. Statistical analysis and preparation of graphs were performed in the software package Stata (StataCorp 2007). Kappa (from the kappa command in Stata) was calculated to determine diagnostic test agreement (infected/not infected) between real-time RT-PCR and virus titration.

\section{RESULTS}

\section{Challenge experiments}

Expt 1

Over the 6 wk study period, 6 fish died in the group exposed to $10^{2} \mathrm{TCID}_{50} \mathrm{ml}^{-1}$, on Days 8 (1 fish), 13 (2 fish), 17 (2 fish) and 20 (1 fish) post challenge (p.c.). No fish died in the group exposed to $10^{3} \mathrm{TCID}_{50} \mathrm{ml}^{-1}$ and 3 died in the group exposed to $10^{4} \mathrm{TCID}_{50} \mathrm{ml}^{-1}(5$, 13 and $17 \mathrm{~d}$ p.c.). VHSV was confirmed in the dead fish by RT-PCR. Two negative control fish were tested by RT-PCR and VHSV was not detected. Since the number of mortalities did not increase with increased viral challenge dose, and even at the highest challenge dose only a few mortalities were observed, the dose for the main challenge experiment was increased. Two challenge doses $\left(5 \times 10^{4} \mathrm{TCID}_{50} \mathrm{ml}^{-1}\right.$ and $5.7 \times 10^{5} \mathrm{TCID}_{50}$ $\mathrm{ml}^{-1}$ VHSV) were used to boost the chance that sufficient numbers of fish would be available for each clinical stage of infection.

\section{Expt 2 (main challenge)}

Mortalities started to occur 5 and $6 \mathrm{~d}$ p.c. in the groups that received the higher and lower challenge 
doses, respectively. Fish for the preclinical group were removed on Days 6 and 7 p.c. from tanks that received the lower challenge dose. Clinically affected fish were removed between Days 7 and 28 p.c. from both groups (25 from the lower challenge dose tanks, 5 from the higher challenge dose tanks). Mortalities used for analysis were removed between Days 6 and 31 (last observed mortality in the low dose challenge group; only fish from the low challenge group were used). Total mortalities were 46 of the 200 fish exposed to the low challenge dose and 35 of the 100 fish exposed to the high challenge dose (Fig. 1). Survivors were removed on the last $2 \mathrm{~d}$ of the experiment (Days 41 and 42 p.c.) from the low challenge group. Of the 30 fish in the survivor group, 17 showed no clinical signs. The other 13 fish were either darkened or showed some reddening or haemorrhaging of the skin; 1 fish showed exophthalmia.

\section{Linearity and amplification efficacy of the real-time assay}

Forty-eight plates, each with 48 wells, were analysed and triplicate sets of the cDNA standard solutions per concentration were run on each plate. The regression line calculated based on all 48 runs was: $C_{t}$ value $=$ $52.9-1.33 \cdot\left(\log _{2}\right.$ of predetermined virus copy number in cDNA).

The 95\% confidence interval for the slope was -1.368923 to -1.298839 . The result was highly significant $\left(F_{1,810}=5582.7, \mathrm{p}<0.0001, \mathrm{R}^{2}=0.87\right)$. Real-time RT-PCR efficacy was 0.683 .

\section{Quantification of virus in tissues (minimum and maximum virus numbers detected, means and medians)}

Results from virus titration and real-time RT-PCR are presented in Table 1 and Fig. 2. VHSV was detected by both methods in the majority of fish in the preclinical and survivor groups, and in all fish of the clinically affected and mortality groups. Virus quantities often varied substantially between clinical stages within each tissue type. Of the 60 tissue samples tested by both methods, 9 samples were negative by titration and 14 by real time RT-PCR. The highest virus measurement was $10^{7.99} \mathrm{TCID}_{50} \mathrm{mg}^{-1}$ in internal organs of a rainbow trout from the preclinical group, and the same fish had virus titres of $10^{6.82} \mathrm{TCID}_{50}$ $\mathrm{mg}^{-1}$ in brain/gill tissue and $10^{5.32} \mathrm{TCID}_{50} \mathrm{mg}^{-1}$ in muscle tissue, which was exceptionally high for its group.

The mean amount of VHSV, grouped by method, tissue and clinical stage, varied from $10^{1.24}$ (virus titration,
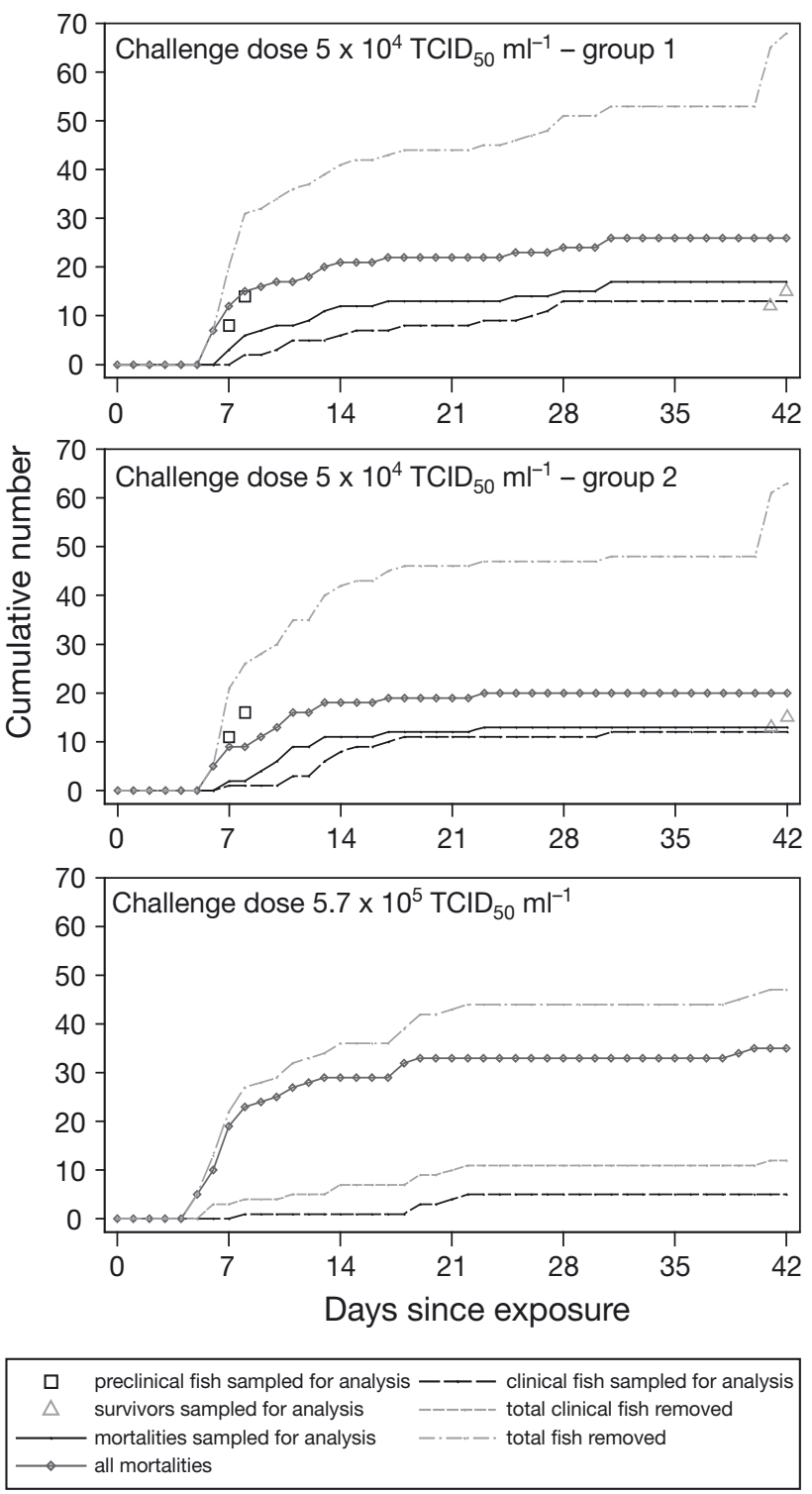

Fig. 1. Oncorhynchus mykiss. Challenge of market-sized rainbow trout with 2 different concentrations of VHSV. Cumulative numbers of fish sampled or removed at different stages of infection are shown. Each graph represents a total of 100 fish. Data displayed for fish exposed to $5.7 \times 10^{5} \mathrm{TCID}_{50}$ were combined from 3 challenge groups into one graph

muscle tissue, survivor group) to $10^{7.29} \mathrm{TCID}_{50} \mathrm{mg}^{-1}$ (virus titration, internal organs, preclinical) (Table 1). Mean values within a clinical stage varied by a factor ranging from 2 to 50 between tissues and in one case by a factor of 460 (TCID $_{50}$ results from preclinical group, where values in internal organs were very high). The spread of virus numbers (minimum, maximum) within each group was substantial. Fish in the preclinical group showed the greatest variability. Less variation was found in clinically affected fish and mortalities (Fig. 2). 


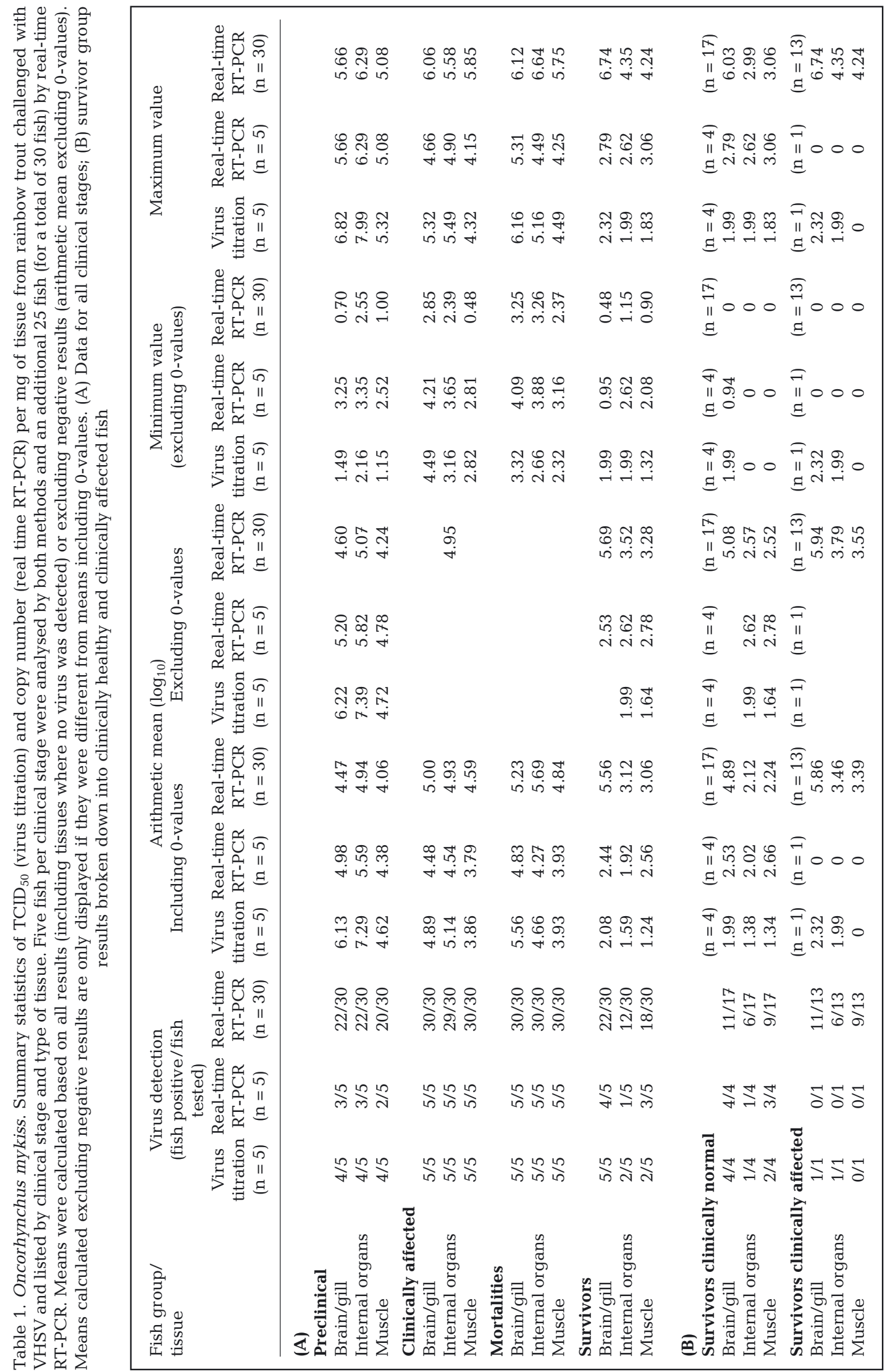




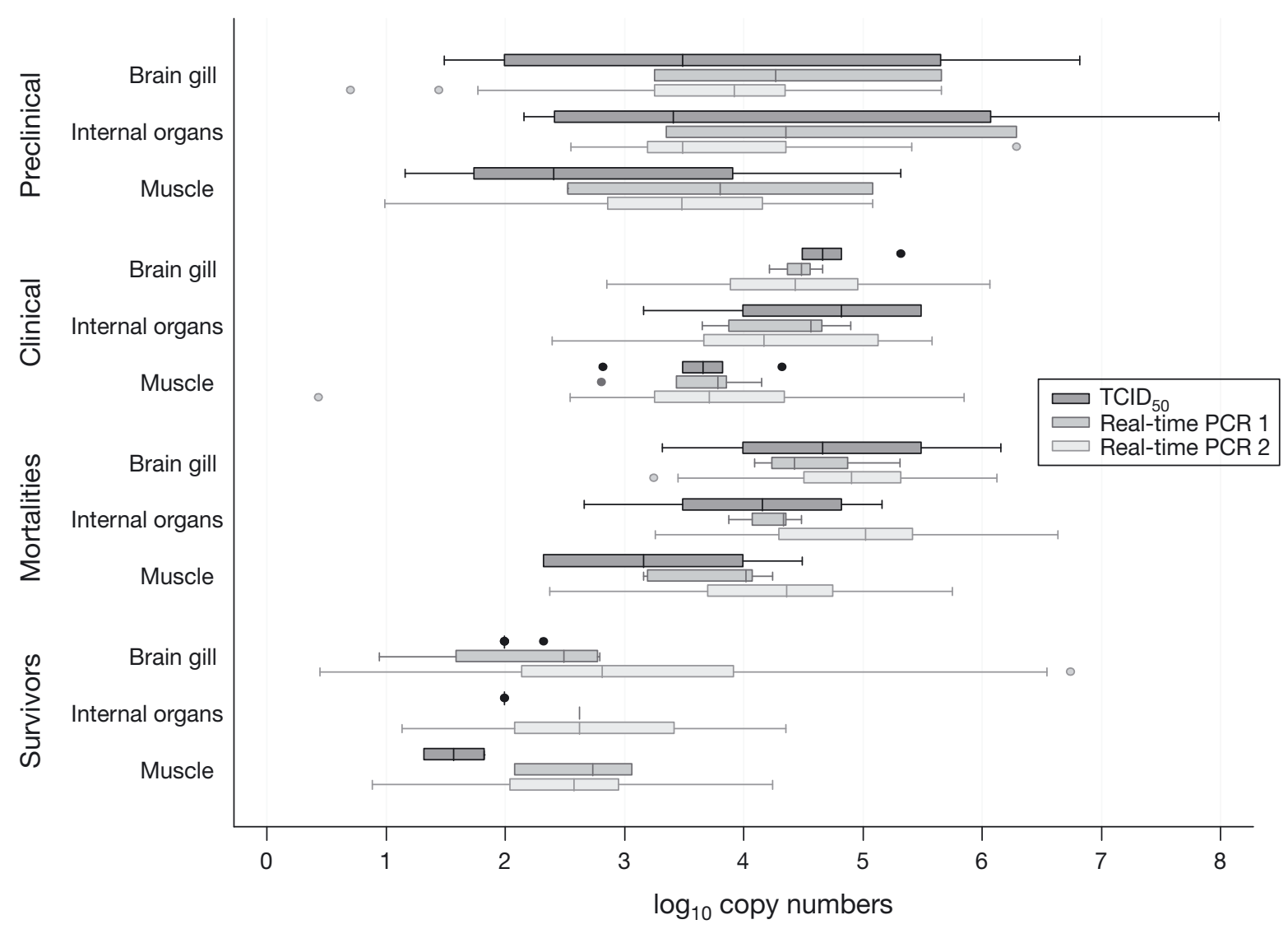

Fig. 2. Oncorhynchus mykiss. Virus particle numbers (displayed as $\log _{10}$ ) in $1 \mathrm{mg}$ of tissue from rainbow trout challenged with VHSV as determined by real-time PCR and tissue culture (TC) titration at various stages of infection. Results of tissues testing negative are not included. Boxes per tissue type from top to bottom are (dark grey) results from 5 fish tested by TC titration $\left(\mathrm{TCID}_{50}\right)$; (mid-grey) real-time PCR results from 5 fish tested by both real-time PCR and tissue culture titration (real-time PCR 1); (light grey) real-time PCR from 30 fish tested by real-time PCR (real-time PCR 2). Line: median; box: 25th-75th percentile; whiskers: lower/upper adjacent values

\section{Quantities of virus in fish tissues within clinical stage groups}

A box plot of measured TCID $_{50}$ and copy numbers in the various tissues and grouped by clinical stage is shown in Fig. 2.

Virus numbers determined by titration differed significantly between types of tissue within each clinical stage for the clinically affected group $(p=0.049$; ANOVA of log-transformed TCID $_{50}$ virus numbers, excluding negative test results, comparing types of tissue within a selected clinical stage; $\mathrm{n}=5$ per type of tissue). In this group, the highest mean and median values were measured in internal organs and brain/gill tissue, and levels were similar in both tissues.

Virus numbers determined by real-time RT-PCR differed significantly between the different types of tissues for the clinically affected group ( $p=0.007)$ and mortalities ( $p=0.005$; ANOVA of log-transformed realtime RT-PCR data, excluding negative test results, comparing types of tissue within a selected clinical stage; $n=30$ per type of tissue). In both groups, the highest mean and median virus numbers were found in internal organs.

In the survivor group, 13 of the 30 trout sampled displayed clinical signs. In fish with clinical signs, copy numbers (determined by real-time RT-PCR) were approximately 1 order of magnitude higher than in fish appearing clinically healthy (Table 1B).

\section{Comparison between clinical stage groups}

Copy numbers detected by real-time RT-PCR differed significantly $(\mathrm{p}<0.0001)$ between clinical stages for all types of tissue (ANOVA of log-transformed real-time RT-PCR data comparing results for various clinical stages within one type of tissue; $\mathrm{n}=$ 30 per clinical stage, excluding negative tests). Clinical stages ordered by the mean and median (the lat- 
ter based only on positive samples) number of copies detected in each respective tissue type tended to be ordered as follows: mortalities $>$ clinical > preclinical and survivors.

TCID $_{50}$ differed significantly between clinical stages only for brain/gill tissue ( $\mathrm{p}=0.01$; ANOVA of logtransformed $\mathrm{TCID}_{50}$ data comparing results for various clinical stages within one type of tissue; $\mathrm{n}=5$ per clinical stage, excluding negative tests). Here the mean titres were ordered as follows: preclinical $>$ mortalities $>$ clinical $>$ survivors.

\section{Comparison of methods}

No differences were found at each clinical stage between RT-PCR measurements of the 5 fish analysed by both virus titration and real-time RT-PCR, and the 25 fish analysed by real-time RT-PCR only (2-sample $t$-tests excluding negative tests, Bonferroni adjustment for multiple tests). No differences were found between $\mathrm{TCID}_{50}$ and real-time RT-PCR measurements of samples analysed by both methods ( $\mathrm{n}=5$ per tissue type and clinical stage; paired $t$-tests). Overall distributions were visually similar (Fig. 2).

\section{Prediction of $\mathrm{TCID}_{50}$ data based on real-time RT-PCR results}

The correlation coefficient (r) between $\log _{10}$ virus titre $\left(\mathrm{TCID}_{50}\right.$ ) and $\log _{10}$ copy numbers (real-time RT$\mathrm{PCR})$ is 0.86 if negative results are included in the

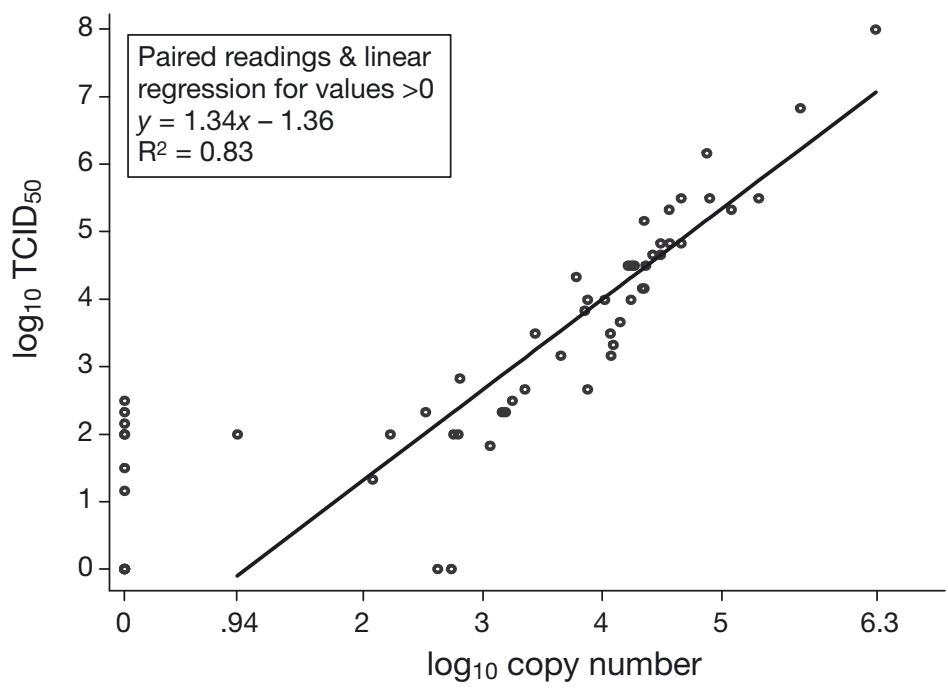

Fig. 3. Oncorhynchus mykiss. $\log _{10}$ real-time PCR results versus $\log _{10}$ of $\mathrm{TCID}_{50}$ using data from 20 fish ( 3 tissues per fish) in which both methods were applied. The fitted curve shows the regression line based on values $>0$ analysis (based on 60 paired values) and 0.91 if negative results are excluded from the analysis (based on 44 paired values). The $\mathrm{R}^{2}$ of the linear regression excluding 0 values is 0.83 ; therefore, $83 \%$ of the variance in the value determined by one method (e.g. the copy numbers determined by real-time RT-PCR) can be explained by its relationship with the infectious dose value determined by the other method (virus titration). $\mathrm{R}^{2}$ of the correlation coefficient including 0 values is 0.73 . The titration method does not predict when the PCR method will record a negative sample.

Fig. 3 shows the fitted regression line between $\log _{10}$ $\mathrm{TCID}_{50}$ (as $y$ ) and $\log _{10}$ real-time RT-PCR $(x)$, where $y=1.34 x-1.36$. The SE for the intercept is 0.377 .

\section{Diagnostic test agreement and sensitivity}

For fish analysed by both methods, virus titration detected more virus-positive fish compared with realtime RT-PCR (Table 2A). Test agreement varied depending on clinical stage of infection. $100 \%$ test agreement was found in clinically affected fish and mortalities (all fish were detected as being infected), whereas test agreement was moderate in the preclinical group $(73.3 \%, 11 / 15$, kappa 0.44$)$ and the survivor group $(66.7 \%, 10 / 15$, kappa 0.32; Table 2B,C).

Virus titration was the more sensitive method in preclinical fish: An additional 4 tissue samples were detected as being infected, whereas no additional samples (tissue samples that had not been detected as being infected by virus titration) were detected by real-time RT-PCR (Table $2 \mathrm{~B}$ ). In the clinically affected fish and mortalities, diagnostic test sensitivity was $100 \%$ for both virus titration and real-time RT-PCR. In the survivor group, titration found 3 and PCR found 2 tissue samples to be infected that were not detected by the other method (Table 2C).

If all the fish in the preclinical group were assumed to be infected, then the diagnostic test sensitivity (dts) using internal organs for both methods is limited and was $73.3 \%$ by real-time RT-PCR (22 out of 30 fish were identified as infected) and $80 \%$ (4 out of 5 fish were detected as being infected) by titration.

In the survivor group, all 5 fish tested by titration were positive for virus in brain/gill tissue, but only 2 in internal organs (dts using internal organs $=40 \%$ ). PCR on the same 5 fish detected virus only in brain/gill tissue of 4 fish (dts $=80 \%$ ), in muscle tissue of 3 fish (dts $=60 \%$ ) and in internal organs of 1 fish (dts $=20 \%$ ).

Another 25 fish from the survivor group were tested by real-time RT-PCR only. The 
Table 2. Oncorhynchus mykiss. Test agreement between tissue culture and real-time PCR analysing tissues (internal organs, brain/gill tissue, muscle tissue) from rainbow trout challenged with VHSV. Results from rainbow trout (A) sampled during all stages of infection (preclinical, clinical signs, mortalities and survivors), (B) sampled during the preclinical stage and $(\mathrm{C})$ sampled from survivors

\begin{tabular}{|c|c|c|c|}
\hline & \multicolumn{2}{|c|}{ Tissue culture result } & \multirow[t]{2}{*}{ Total } \\
\hline & Negative & Positive & \\
\hline \multicolumn{4}{|c|}{ (A) All stages of infection } \\
\hline PCR result: Negative & 7 & 7 & 14 \\
\hline Positive & 2 & 44 & 46 \\
\hline Total & 9 & 51 & 60 \\
\hline \multicolumn{4}{|l|}{ (B) Preclinical } \\
\hline PCR result: Negative & 3 & 4 & 7 \\
\hline Positive & 0 & 8 & 8 \\
\hline Total & 3 & 12 & 15 \\
\hline \multicolumn{4}{|l|}{ (C) Survivors } \\
\hline PCR result: Negative & 4 & 3 & 7 \\
\hline Positive & 2 & 6 & 8 \\
\hline Total & 6 & 9 & 15 \\
\hline
\end{tabular}

number of fish within this group that were truly infected is unknown. Therefore, the diagnostic test sensitivity cannot reliably be determined. If all were assumed to be infected, then the diagnostic test sensitivity varied with the tissue, ranging from $40 \%$ (12 out of 30 internal organs samples) through $60 \%$ (18 out of 30 muscle samples) to $73.3 \%$ (22 out of 30 brain/gill samples).

\section{DISCUSSION}

\section{Challenge dose}

Expt 1 aimed to establish a suitable virus concentration to challenge market-sized rainbow trout with VHSV, generating mortalities and survivors. Published information on virus challenge doses using rainbow trout is mainly on fry or fingerlings. Only 1 study reported experimental infection of market-sized fish (Neukirch 1992) and showed that the final mortality was related to virulence of the virus and water temperature. Hence, we needed to determine experimental conditions for our virus isolate.

We have shown that a relatively high challenge dose was required under the experimental conditions to produce a mix of all clinical stages (subclinical, clinically affected fish and mortalities) in a population of market-sized rainbow trout. These results indicated virus concentrations that might be present in water if a similar presentation of the disease in terms of mortality rates and prevalence of clinically affected fish were found in a farmed population.

\section{Virus concentrations}

Our main objective was to investigate virus levels that may be found in rainbow trout imported for human consumption (e.g. in whole eviscerated fish) and measure virus levels in tissues at various stages of infection. Fish were preferentially sampled from the tank that received the lower challenge dose, since this was considered to better imitate conditions on a farm than was the higher challenge dose. However, for practical reasons (number of fish available per challenge dose and number of fish that could be sampled on a single day) this was not always possible. Virus concentrations varied widely in tissues of subclinically infected fish, but less widely in tissues of clinically infected fish and mortalities. Significant virus levels could be found before onset of clinical signs. Muscle tissue carried a lower virus concentration per milligram of tissue than did brain/gill tissue or internal organs at each stage of infection except in the survivor group, for which virus concentration in muscle tissue was similar to that in internal organs. This may have implications when infected stocks are culled and processed for human consumption. Viral load in brain/gill and muscle tissues of fish in the preclinical group reached extremely high values (brain/gill tissue: up to $6.65 \times 10^{6} \mathrm{TCID}_{50}$ and $4.5 \times 10^{5}$ copies $\mathrm{mg}^{-1}$; muscle tissue: up to $2.10 \times 10^{5} \mathrm{TCID}_{50}$ and $1.21 \times 10^{5}$ copies $\mathrm{mg}^{-1}$ ). The survivor group contained both clinically affected and healthy appearing fish. Virus levels were higher by a factor of about 1 order of magnitude amongst the survivors displaying clinical signs. We have also shown that the viral load in individual fish that survived exposure to VHSV can be extremely high in brain/gill tissue $\left(5.5 \times 10^{6} \mathrm{TCID}_{50} \mathrm{mg}^{-1}\right)$.

Few other studies have investigated virus levels in tissues of VHSV infected fish, and most used internal organs and a variety of fish species (rainbow trout, Pacific herring Clupea harengus pallasi, Pacific sardine Sardinops sagax, hake Merluccius productus and pollock Theragra chalcogramma) (Jorgensen 1970, Meyers et al. 1994, 1999, Kocan et al. 1997, 2001, Arkush et al. 2006). Only one previous study reported virus levels in muscle tissue. Wolf et al. (1968) investigated virus levels in VHSV infected rainbow trout and reported virus concentrations of $10^{2.5}$ to $10^{4.5} \mathrm{TCID}_{50}$ $\mathrm{g}^{-1}$ in muscle tissue sampled from 5 fish that had been stored whole at $-20^{\circ} \mathrm{C}$ for 8 mo before testing. No other studies have provided virus levels in brain or gills.

Most studies included periods of transport and storage, and sometimes freezing and thawing, before processing samples to determine viral titres. Both storage and freezing appear to reduce the detectable virus levels. Arkush et al. (2006) reported that transport of fish for a few hours ( $<8 \mathrm{~h}$ on ice) followed by a freeze-thaw 
cycle reduced the virus levels by 3 orders of magnitude. Jorgensen (1970) reported that viral titres declined by 1 order of magnitude when stored for $44 \mathrm{~h}$ at $4{ }^{\circ} \mathrm{C}$. When the effects of storage and freezing used in other studies are taken into account, results reported in this study on virus titres in internal organs are similar to results reported previously.

No data were found on the loss of infectivity in tissues imported for human consumption, such as muscle tissue. All experimental studies on loss of titre over time or after freezing used internal organs. Studies are therefore required that provide information on the virus levels of tissues imported for human consumption.

A relatively high challenge dose was required to produce the mix of clinical stages required for this study. It would be likely on a farm to find low virus concentrations in the water at the onset of an epidemic, which could rise to possibly very high levels as prevalence of infection within the affected population increased. Therefore, the viral load in tissues of preclinical fish in a farm setting may be lower than reported here. This possibility will need to be explored in further studies. The virus levels reported for clinically healthy survivors are, however, likely to represent values that may be found in farmed fish, since the effect of the artificial challenge would be expected to have worn off by the time of sampling.

\section{Comparison of detection methods}

The large number of samples necessitated a cheaper and less time-intensive method for determining virus quantities than virus titration; real-time RT-PCR was identified as an alternative. It was therefore important to assess how well measurements made by real-time RTPCR corresponded to quantities reported by virus titration, since the latter is considered the 'gold standard' for estimating the quantity of viable virus. We found good agreement between the 2 methods, particularly at virus titres around $10^{4} \mathrm{TCID}_{50} \mathrm{mg}^{-1}$ tissue. Below that value, virus titration returned slightly lower readings than those obtained by real-time RT-PCR, and above it they were slightly higher. The differences were, however, not substantial and we reported the original real-time data alongside $\mathrm{TCID}_{50}$ values rather than applying any adjustment. There was no indication that PCR measurements overestimated the number of virus copies due to the presence of viral mRNA expressed in host tissue.

\section{Test performance}

Although our study was not set up to compare diagnostic test performances, this was worth exploring. Nei- ther method is currently the recommended method to detect VHSV for statutory purposes. However, real-time RT-PCR has recently been recommended to be applied in settings where VHSV is considered endemic and may be more sensitive than cell culture (Hope et al. 2010).

Diagnostic test sensitivity is the ability of a diagnostic test to correctly identify an organism as being infected if it is actually infected. It is expressed as the number of organisms detected as being infected divided by the number of those that are truly infected. In our study the diagnostic test sensitivity was compared over the tissues and stages of infection. Regardless of the test method, the use of internal organs resulted in a high diagnostic test sensitivity (dts) in fish during incubation, moribund fish and mortalities. However, in survivors, internal organs provided the lowest chance of detecting the virus, while using both muscle tissue and brain/gill tissue resulted in a higher dts. Current EU legislation (EU commission decision 2001/183) and international guidelines (OIE 2009) require that spleen, anterior kidney and either heart or encephalon are sampled for virus detection. Further studies would be useful to explore whether the high test sensitivity observed in our study for the limited number $(n=5)$ of brain/gill samples tested by virus titration from the survivor group can be confirmed. Given that gill tissue is far more convenient to sample compared with brain, it would also be useful to further investigate the virus levels present in gill tissue alone.

Our study challenged fish with a relatively high virus dose to induce infection. This does not imitate a real farm situation, where a low level of virus may be introduced and prevalence of infection would be expected to be very low during incubation. Current guidelines (OIE 2009) and EU legislation allow for samples from up to 10 fish to be pooled. A reduction of virus titres between sampling of tissues in the field and processing for cell culture inoculation at the laboratory may also lead to a drop in viable virus levels below the limit of detection. If the samples are pooled (infected and uninfected fish), there could be a risk that virus levels may drop below the level of detection.

The observed higher test sensitivity of virus titration compared to real-time RT-PCR, especially in the preclinical group, could be due to the larger amount of tissue used in virus titration compared with real-time RTPCR. The virus titres per millgram tissue in those cases where titration was positive and real-time RT-PCR was negative were very low (30 to 300 infectious doses $\mathrm{mg}^{-1}$ tissue). The amount of tissue actually used per tissue type and fish on a 96 well plate in virus titration was determined to be $12 \mathrm{mg}$. The amount of tissue analysed by real-time RT-PCR was only $0.08 \mathrm{mg}$, or 150 times less, which may explain the differences in test performance. 
Cell culture methods, following the recommended procedures as advised in EU commission decision 2001/183, may use higher total amounts of tissue inoculated onto cell cultures compared with titration. Whereas $12 \mathrm{mg}$ of tissue were effectively inoculated using titration, the total amount of tissue inoculated using the statutory cell culture method is in the order of 27 to $54 \mathrm{mg}$ (following Cefas Standard Operating Procedures). In addition, subcultivation is required if no cytopathic effect was observed after a defined time period, further increasing the chance of detection. Therefore, assuming a given concentration of virus in a sample, the statutory method is more likely to detect the virus compared with virus titration. To what extent this higher sensitivity may be diluted by pooling samples would depend on the number of samples combined in a pool.

Several factors may influence the performance of a real-time PCR assay, from the handling and storage of the samples to primer and probe design. However, this study indicates that other factors such as total amount of tissue used for an analysis should to be taken into account when interpreting test results. Our results initially appear to conflict with reports by Hope et al. (2010), who reported a higher test sensitivity for realtime PCR compared with cell culture. This is probably explained by Hope et al.'s (2010) use of tissues that were frozen before submitting them to cell culture. Based on data from previous studies, freezing is likely to lead to a drop in virus titres of 3 orders of magnitude.

We recommend more studies to investigate virus levels in tissues of fish after they have been slaughtered. It would also be useful to establish whether results of virus titration and real-time RT-PCR agree as well when samples are taken from fish that have been frozen or stored as they do from fresh samples. The study by Hope et al. (2010) would suggest that this may be unlikely.

Manufacturers advise setting up standards by establishing a dilution series from a cDNA stock solution. Previous studies that followed this method (Chico et al. 2006) found a good RT-PCR efficiency. However, we felt that following this method ignores potential losses in the efficacy of transcription that may occur in the presence of high amounts of host tissue RNA. cDNAs generated from fish samples spiked with a calculated RNA copy number of $10^{6}$ to $10^{2}$ were initially used to set up a standard curve for this study. However, if RNA copy numbers of above $5.0 \times 10^{5}$ and below $1.5 \times 10^{3}$ are used, repeatability was poor (the triplicate runs provided increasingly varying $C_{t}$ values). Therefore, we used a doubling dilution series from $2.0 \times 10^{5}$ to $6.25 \times 10^{3}$ copies as recommended by the manufacturer, which then produced a standard curve with desired characteristics. In future studies it will be important to compare the efficacy of the real-time RT-PCR by means of a dilution series established from spiked host RNA extract as described here versus a dilution series generated from pure pathogen RNA or cDNA. This will help to establish which material is the most appropriate in the preparation of a standard curve when real-time assays are used for quantitative analysis.

In this exploratory study, we pooled brain and gill tissues to limit the number of samples processed. Given that we found that pools of these tissues contain relevant virus quantities, further studies are recommended to analyse viral load in these tissues separately. To complete the information on viral load in fish commodities imported for human consumption, it would also be important to determine viral load in skin and mucus, especially since these are usually disposed of as waste. To assess the infectivity of tissues infected with VHSV, it is also necessary to know the minimal infectious dose of VHSV for susceptible species, but there are currently no published values.

\section{CONCLUSIONS}

We found substantial virus concentrations in tissues of rainbow trout that showed no clinical signs of VHS. This was especially the case in the preclinical group. Virus concentrations were not only high in internal organs, but also in brain/gill tissue and muscle tissue, suggesting that eviscerated fish may not necessarily represent a safe commodity.

In countries where fish farmers are not compensated for compulsory fish culls, emergency slaughter may be allowed to limit the financial impact on the fish farming business. Whilst diseased fish are unlikely to enter the food chain, infected fish (preclinical or survivors) from VHSV endemic regions can be slaughtered and processed for human consumption. Under EU legislation there are currently no restrictions on the import of such fish into areas free from the disease if eviscerated, and they therefore represent a route of VHSV introduction. Further investigations are required to assess the amounts of virus that may be released from such a consignment, exposure pathways and the potential to infect farmed or wild fish.

Acknowledgements. We thank Dr. E. Peeler and the reviewers for valuable comments to the manuscript. This work was funded under Defra projects F1165 and F1190. Finally, we thank the staff in our experimental facility for excellent support and a number of Cefas colleagues for assistance with sampling.

\section{LITERATURE CITED}

Arkush KD, Mendonca HL, McBride AM, Yun S, McDowell TS, Hedrick RP (2006) Effects of temperature on infectivity and of commercial freezing on survival of the North American strain of viral hemorrhagic septicemia virus (VHSV). Dis Aquat Org 69:145-151 
Chico V, Gomez N, Estepa A, Perez L (2006) Rapid detection and quantitation of viral hemorrhagic septicemia virus in experimentally challenged rainbow trout by real-time RTPCR. J Virol Methods 132:154-159

> Dixon PF, Avery S, Chambers E, Feist S and others (2003) Four years of monitoring for viral haemorrhagic septicaemia virus in marine waters around the United Kingdom. Dis Aquat Org 54:175-186

Einer-Jensen K, Ahrens P, Forsberg R, Lorenzen N (2004) Evolution of the fish rhabdovirus viral haemorrhagic septicaemia virus. J Gen Virol 85:1167-1179

Elsayed E, Faisal M, Thomas M, Whelan G, Batts W, Winton J (2006) Isolation of viral haemorrhagic septicaemia virus from muskellunge, Esox masquinongy (Mitchill), in Lake St Clair, Michigan, USA reveals a new sublineage of the North American genotype. J Fish Dis 29:611-619

Groocock GH, Getchell RG, Wooster GA, Britt KL and others (2007) Detection of viral hemorrhagic septicemia in round gobies in New York State (USA) waters of Lake Ontario and the St. Lawrence River. Dis Aquat Org 76:187-192

Hill BJ, Underwood BO, Smale CJ, Brown F (1975) Physicochemical and serological characterization of five rhabdoviruses infecting fish. J Gen Virol 27:369-378

Hope KM, Casey RN, Groocock GH, Getchell RG, Bowser PR, Casey JW (2010) Comparison of quantitative RT-PCR with cell culture to detect viral hemorrhagic septicemia virus (VHSV) IVb infections in the Great Lakes. J Aquat Anim Health 22:50-61

Jorgensen PEV (1970) Untersuchungen über das EgtvedVirus: Seine Stabilität und Identifizierung. Muench Beitr Abwasser- Fisch Flussbiol 18:60-71

- Kärber G (1931) Beitrag zur kollektiven Behandlung pharmakologischer Reihenversuche. Archiv Exp Pathol Pharmakol 162:480-487

Kocan R, Bradley M, Elder N, Meyers T, Batts W, Winton J (1997) North American strain of viral hemorrhagic septicemia virus is highly pathogenic for laboratory-reared Pacific herring. J Aquat Anim Health 9:279-290

- Kocan RM, Hershberger PK, Elder NE, Winton JR (2001) Epidemiology of viral hemorrhagic septicemia among juvenile Pacific herring and Pacific sand lances in Puget Sound, Washington. J Aquat Anim Health 13:77-85

Lannan CN, Winton JR, Fryer JL (1984) Fish cell lines: establishment and characterization of nine cell lines from salmonids. In Vitro 20:671-676

Lumsden JS, Morrison B, Yason C, Russell S and others (2007) Mortality event in freshwater drum Aplodinotus grunniens from Lake Ontario, Canada, associated with viral haemorrhagic septicemia virus, Type IV. Dis Aquat Org 76:99-111

Meyers TR, Short S, Lipson K, Batts WN, Winton JR, Wilcock J, Brown E (1994) Association of viral hemorrhagic septicemia virus with epizootic hemorrhages of the skin in Pacific herring Clupea harengus pallasi from Prince William Sound and Kodiak Island, Alaska, USA. Dis Aquat Org 19:27-37

Editorial responsibility: Mark Crane, Geelong, Victoria, Australia
Meyers TR, Short S, Lipson K (1999) Isolation of the North American strain of viral hemorrhagic septicemia virus (VHSV) associated with epizootic mortality in two new host species of Alaskan marine fish. Dis Aquat Org 38: 81-86

Neukirch M (1992) VHSV-infected rainbow trout, Oncorhynchus mykiss - a model for the study of temperature dependant excretion of viral agents. In: Shariff M, Subasinghe RP, Arthur JR (eds) 1. Symposium on diseases in Asian aquaculture, Bali (Indonesia), 26-29 November 1990. Fish Health Section, Asian Fisheries Society, Manila, p 273-280

OIE (World Organisation for Animal Health) (2008) Aquatic animal health code, 11th edn. OIE, Paris, available at www.oie.int/Eng/normes/fcode/A_summry.htm (accessed 3 Nov 2008)

OIE (World Organisation for Animal Health) (2009) Manual of diagnostic tests for aquatic animals. OIE, Paris, available at www.oie.int/eng/normes/fmanual/A_summry.htm (accessed 9 Apr 2010)

> Olesen NJ (1998) Sanitation of viral haemorrhagic septicaemia (VHS). J Appl Ichthyol 14:173-177

Parry L, Dixon PF (1997) Stability of nine viral haemorrhagic septicaemia virus (VHSV) isolates in seawater. Bull Eur Assoc Fish Pathol 17:31-36

Raja-Halli M, Vehmas TK, Rimaila-Pärnänen E, Sainmaa S, Skall HF, Olesen NJ, Tapiovaara H (2006) Viral haemorrhagic septicaemia (VHS) outbreaks in Finnish rainbow trout farms. Dis Aquat Org 72:201-211

Skall HF, Slierendrecht WJ, King JA, Olesen NJ (2004) Experimental infection of rainbow trout Oncorhynchus mykiss with viral haemorrhagic septicaemia virus isolates from European marine and farmed fishes. Dis Aquat Org 58: 99-110

Skall HF, Olesen NJ, Mellergaard S (2005) Viral haemorrhagic septicaemia virus in marine fish and its implications for fish farming - a review. J Fish Dis 28:509-529

> Snow M, Bain N, Black J, Taupin V and others (2004) Genetic population structure of marine viral haemorrhagic septicaemia virus (VHSV). Dis Aquat Org 61:11-21

> Stone DM, Way K, Dixon PF (1997) Nucleotide sequence of the glycoprotein gene of viral haemorrhagic septicaemia (VHS) viruses from different geographical areas: a link between VHS in farmed fish species and viruses isolated from North Sea cod (Gadus morhua L.). J Gen Virol 78: $1319-1326$

Stone DM, Ferguson HW, Tyson PA, Savage J and others (2008) The first report of viral haemorrhagic septicaemia in farmed rainbow trout, Oncorhynchus mykiss (Walbaum), in the United Kingdom. J Fish Dis 31:775-784

Wolf K, Gravell M, Malsberger RG (1966) Lymphocystis virus: isolation and propagation in a centrarchid fish cell line. Science 151:1004-1005

Wolf K, Bullock GL, Dunbar CE, Quimby MC (1968) Viral diseases of freshwater fishes and other lower vertebrates (General). Prog Sport Fish Res 1968:136-141

Submitted: July 29, 2010; Accepted: October 12, 2010 Proofs received from author(s): January 18, 2011 